\title{
Tata Laksana Pengelolaan Pakan Sapi Potong
}

\section{Feeding Management of Beef Catlle}

\author{
D Ardiansyah ${ }^{1}, \mathbf{N}$ Irwani $^{1 *}$, Y Priabudiman ${ }^{1}$ \\ ${ }^{1}$ Jurusan Peternakan Politeknik Negeri Lampung, \\ Jln. Soekarno Hatta No 10 Rajabasa Bandar Lampung, 35144 \\ * E-mail korespondensi: naniirwani@polinela.ac.id
}

\begin{abstract}
Cattle fattening in Indonesia use a dry lot fattening system, which is a fattening system in a cage, and the feed is rationed or served. The feed has a high contribution of around $75 \%$ in production costs. The purpose of this Final Project Report is to understand the feed management of beef cattle at PT Indo Prima Beef. Data was collected using interviews, observation, and library methods. Feed planning is done 2 times, in the morning \pm 06.00 to see the consumption of the night and during the day \pm 13.00 to see the morning consumption. Feed distribution at PT Indo Prima Beef is divided into 2, the distribution of forage feed and the distribution of concentrate feed. PT Indo Prima Beef made 2 types of concentrates which named F8 and F9. F8 is a concentrate that has $20 \%$ protein content and $63 \%$ of energy (TDN). F8 concentrate was made for the grower period while F9 concentrate made for the finisher period. F9 has a higher energy content (TDN) of 69\% and a lower protein content of $18 \%$.
\end{abstract}

Keywords: beef cattle, feed, management

Diterima: Disetujui:

\section{PENDAHULUAN}

Indonesia adalah suatu negara yang memiliki sumber daya alam yang sangat melimpah sehingga terdapat banyak sektor yang dikembangkan di Indonesia salah satunya sektor peternakan, di Indonesia sendiri sektor perternakan dari tahun ke tahun berkembang cukup pesat seperti contohnya peternakan sapi. Dahulu sapi hanya dipelihara oleh petani saja dan hanya untuk membantu mengolah tanah, membawa hasil pertanian, dipelihara sebagai tabungan. Seiring berkembangnya zaman perternakan sapi mulai dijadikan sebagai ladang bisnis, alasannya karena prospek bisnis peternak sapi memiliki peluang yang cukup besar, terlebih lagi laju pertumbuhan ekonomi Indonesia meningkat setiap tahunnya rata-rata sebesar 6\%, sementara jumlah penduduk Indonesia meningkat rata-rata $1,15 \%$ per tahun. Pada Tahun 2015 jumlah penduduk Indonesia mencapai $\pm 237,5$ juta jiwa (Badan Pusat Statistik, 2015). Seiring dengan meningkatnya jumlah penduduk yang diikuti dengan kenaikan pertumbuhan ekonomi Indonesia, maka diperkirakan kebutuhan konsumsi protein hewani khususnya yang bersumber dari daging sapi juga akan meningkat. Hal ini akan memperluas prospek bisnis peternakan sapi dalam bidang penggemukan sapi potong atau feedlot. Pada umumnya penggemukan sapi di Indonesia menggunakan sistem penggemukan dry lot fattening yaitu sistem penggemukan di dalam kandang, ternak tidak dilepas dan pemberian pakan secara dijatah atau disuguhkan. Pakan memiliki kontribusi yang tinggi sekitar $75 \%$ dalam biaya produksi. Salah satu 
perusahaan yang berjalan di bidang sapi potong yaitu PT Indo Prima Beef. PT Indo prima Beef menerapkan tata laksana pemberian pakan untuk meningkatkan produktivitas sapi potong.

\title{
MATERI DAN METODE
}

\section{Tempat dan Waktu Pelaksanaan}

Pengambilan data dilakukan selama 2 bulan dimulai dari tanggal 20 Februari 2017 sampai dengan 20 April 2017 yang bertempat di PT Indo Prima Beef yang beralamatkan di Desa Adi Jaya Kecamatan Terbanggi Besar, Kabupaten Lampung Tengah.

\begin{abstract}
Alat dan Bahan
Alat-alat yang digunakan adalah gudang penyimpanan bahan pakan, Mixer adalah pengaduk bahan konsentrat, roli (angkong), plastik untuk penutup pada proses fermentasi tebon, pembalik pakan, timbangan untuk menimbang bahan pakan, chopper untuk mencacah tebon jagung. Bahan-bahan yang digunakan antara lain bahan pakan konsentrat antara lain bungkil kedelai, bungkil kopra, bungkil sawit, pollard (dedak gandum), onggok, elot, molasses, SB (Sodium Bicarbonat), DCP (Dicalcium Fosfat), urea dan kapur, bahan pakan hijauan antara lain tebon segar dan silase tebon.
\end{abstract}

\section{Metode Pengumpulan Data}

Pengumpulan data dilakukan dengan metode interview, observasi, dan Metode pustaka

\section{Pengamatan}

Pengamatan yang dilakukan meliputi perencanaan pakan, pengadaan bahan pakan, pencampuran konsentrat (mixing), pendistribusian, pemberian pakan

\section{HASIL DAN PEMBAHASAN}

\section{Perencanaan Pakan}

Perencanaan pakan adalah suatu kegiatan untuk merencanakan pakan yang akan diberikan pada setiap kandang berdasarkan jumlah populasi sapi dan bobot badan. Perencanaan pakan di PT Indo Prima Beef dilakukan dengan cara kepala gudang mengelilingi setiap kandang dan melihat pakan yang tersisa dalam tempat pakan. Perencanaan pakan dilakukan 2 kali yaitu pagi hari \pm pukul 06.00 untuk melihat konsumsi malam dan siang hari \pm pukul 13.00 untuk melihat konsumsi pagi.

Apabila pakan habis dilakukan tindakan penambahan jumlah pakan atau sama seperti hari sebelumnya, tetapi apabila terdapat pakan sisa maka perlu adanya perubahan rencana pakan dengan cara mengurangi jumlah pemberian pakan. Penanganan pakan sisa yaitu dengan dikumpulkan dari semua kandang dan diberikan kepada sapi betina yang sedang bunting. Pemberian pakan di PT Indo Prima Beef dibagi menjadi 2 yaitu $40 \%$ diberikan saat pagi hari dan $60 \%$ diberikan saat sore hari.

\section{Pengadaan Bahan Pakan}

Pengadaan bahan pakan di PT Indo Prima Beef, baik pakan hijauan atau konsentrat terbilang mudah karena letak peternakan yang berada di Lampung Tengah yang merupakan daerah sektor pertanian, baik berupa lahan pertanian dan industri pengolahan hasil pertanian, yang dimana memiliki limbah yang dapat dijadikan pakan ternak sehingga mudah untuk mendapatkan bahan pakan. Menurut Siregar (2003), biaya pakan memiliki kontribusi yang cukup besar dalam pemeliharaan sapi potong, sehingga kita mencari pakan yang murah tetapi memiliki nutrisi yang bagus, seperti halnya limbah pertanian atau industri pertanian. Daftar bahan pakan dan asal bahan pakan di PT Indo Prima Beef dapat dilihat pada Tabel 1. 
Tabel 1. Bahan pakan dan asal bahan pakan di PT Indo Prima Beef

\begin{tabular}{llc}
\hline Bahan Pakan & Asal Bahan Pakan & Harga (Rp)/kg \\
\hline Batang jagung & petani sekitar Lampung Tengah & 500 \\
Bungkil kelapa sawit & PTPN 7 Bekri Lam-Teng & 1.650 \\
Bungkil kelapa & JAMBI & 2.950 \\
Dedak gandum & PT Boga Sari & 3.200 \\
Distillers grain (DgS) & PT Berkat Argri Raya Surabaya & 3.750 \\
Bungkil kedelai & Argentina & 2.700 \\
Onggok & lokal Lampung & 1.600 \\
Ellot & lokal Lampung & 2.510 \\
\hline
\end{tabular}

Sumber : PT Indo Prima Beef (2017)

\section{Pengadaan Hijauan}

Pengadaan hijauan di PT Indo Prima Beef, dalam memenuhi kebutuhan pakan yang diberikan pada ternak memanfaatkan limbah pertanian atau hasil pertanian. Hijauan yang diberikan berupa hijauan segar dan silase. Hijauan segar yang diberikan berupa tebon jagung atau jagung yang berumur $\pm 75-80$ hari. Menurut Kushartono dan Iriani (2003) jagung yang berumur 70 - 80 hari memiliki kandungan nutrisi yang tidak kalah dengan rumput raja, seperti yang dapat dilihat pada Tabel 2.

Tabel 2. Perbandingan nutrisi tanaman jagung dan rumput raja

\begin{tabular}{llllll}
\hline Jenis tanaman & PK $(\%)$ & Lemak $(\%)$ & SK $(\%)$ & Abu(\%) & energi(\%) \\
\hline Tanaman jagung & 12.57 & 3.31 & 23.30 & 6.33 & 34.87 \\
Rumput raja & 10.62 & 2.64 & 30.40 & 9.23 & 13.60 \\
\hline
\end{tabular}

Sumber : PT Family Sejahtera, (2002)

Pengadaan tebon jagung di PT Indo Prima Beef, perusahaan bekerjasama dengan suplayer untuk menyuplai tebon jagung yang berasal dari petani jagung di Lampung Tengah dan sekitarnya dengan harga Rp $400-500 / \mathrm{kg}$. Sebelum hijauan diberikan kepada ternak dilakukan beberapa proses yaitu :

1. Penimbangan

Penimbangan bertujuan untuk mengetahui berat hijauan, sistem penimbangan di PT Indo Prima Beef yaitu dengan cara menimbang beserta kendaraannya. Cara menghitungnya yaitu = berat mobil berisi angkutan - berat mobil kosong.

2. Pencacahan

Menurut Sunarso dan Cristiyanto (2008) pencacahan pada hijauan akan meningkatkan konsumsi dan nilai kecernaannya, sedangkan ukuran cacahan dengan kecernaan yang terbaik adalah $\pm 3-5 \mathrm{~cm}$. Pencacahan hijauan di PT indo Prima Beef bertujuan untuk mencacah hijauan agar mudah dikonsumsi oleh ternak dan lebih efisien karena dapat mengurangi pakan yang tercecer dan ukuran cacahanya bervariasi antara $5-10 \mathrm{~cm}$.

3. Pengemasan dalam karung

Tujuan pengarungan adalah untuk memudahkan dalam proses pendistribusian dengan bobot per karung $25 \mathrm{~kg}$. Dalam sehari PT Indo Prima Beef membutuhkan hijauan \pm 10 ton dan jika dikarungkan \pm menjadi 388 karung. 


\section{Jurnal Peternakan Terapan}

\section{Pengolahan Silase}

Pengadaan hijauan berupa silase, dilakukan beberapa proses yaitu Penimbangan, Pencacahan dan Fermentasi tebon jagung. Tebon jagung yang sudah dicacah kemudian ditumpuk pada suatu tempat yang memiliki dinding dengan tinggi $150 \mathrm{~cm}$, bebentuk huruf $U$ dan memiliki atap. Saat proses pencacahan tebon jagung, dilakukan pemadatan dengan tujuan efisiensi tempat, agar tidak ada udara atau rongga karena akan mempengaruhi keberhasilan fermentasi. Proses fermentasi di PT Indo Prima Beef menggunakan sistem tanpa udara (anaerob) dan setiap ketinggian tumpukan $\pm 30 \mathrm{~cm}$ disiram molasses yang sudah dilarutkan air dan diberikan secara merata di atas permukaan. Langkah terakhir yaitu tutup tumpukan dengan plastik hitam dan diamkan selama 14 hari. Ciri - ciri silase yang baik adalah berbau harum, berwarna kuning kehijauan (BPTP, 2012). PT Indo Prima Beef membutuhkan 10 ton tebon jagung atau \pm 2 truk tebon jagung untuk memenuhi kebutuhan sapi \pm 1500 ekor/ hari.

\section{Pengadaan Konsentrat}

Bahan pakan dalam campuran konsentrat di PT Indo Prima Beef berasal dari limbah industri hasil pertanian. Bahan pakan dalam campuran konsentrat di PT Indo Prima Beef dapat dilihat pada Tabel di bawah ini

Tabel 3. Bahan pakan dalam campuran konsentrat

\begin{tabular}{lrrrrrrc}
\hline Bahan Pakan & $\begin{array}{r}\text { BK } \\
(\boldsymbol{\%})\end{array}$ & $\begin{array}{r}\text { PK } \\
(\boldsymbol{\%})\end{array}$ & $\begin{array}{r}\text { SK } \\
(\boldsymbol{\%})\end{array}$ & $\begin{array}{r}\text { TDN } \\
(\boldsymbol{\%})\end{array}$ & $\begin{array}{r}\text { ME } \\
(\mathbf{m c a l} / \mathbf{k g})\end{array}$ & $\begin{array}{c}\text { Ca } \\
(\boldsymbol{\%})\end{array}$ & $\begin{array}{c}\text { P } \\
(\boldsymbol{\%})\end{array}$ \\
\hline Bungkil kelapa & 86.0 & 20.40 & 9.0 & 80.0 & - & 0.31 & 0.85 \\
Dedak gandum & 89.0 & 18.20 & 11.1 & 70.0 & 2.63 & 0.14 & 1.43 \\
Distillers grain (DgS) & 92.0 & 29.55 & 13.0 & 84.0 & 3.29 & 0.10 & 0.40 \\
Bungkil kedelai & 86.0 & 44.20 & 15.8 & 66.0 & 2.50 & 0.22 & 1.34 \\
Onggok & 91.0 & 4.00 & 15.0 & 65.0 & 2.65 & 0.10 & 0.35 \\
Ellot & 88.7 & 1.20 & 3.7 & 69.0 & 2.75 & 0.20 & 0.20 \\
Molasses & 86.0 & 2.20 & 26.9 & 65.0 & 2.45 & 0.68 & 0.05 \\
Sodium bicarbonate & 86.0 & - & - & - & - & 37.0 & - \\
Dicalcium Fosfat & & & & & & 21.0 & 18.50 \\
Urea & 100.0 & 287.00 & & & & & \\
Kapur & 86.0 & & & & & & \\
\hline
\end{tabular}

Bahan pakan konsentrat datang ke PT Indo Prima Beef terdapat beberapa proses yaitu

1. Penimbangan

Penimbangan bertujuan untuk mengetahui berat hijauan. Sistem penimbangan di PT Indo Prima Beef yaitu dengan cara menimbang beserta kendaraanya Cara menghitungnya yaitu = berat mobil berisi angkutan - berat mobil kosong

2. Uji fisik

Ketika bahan pakan konsentrat datang kemudian ditimbang, kepala gudang melakukan uji fisik antara lain seperti bentuk, bau, warna dan kadar air.

3. Penyimpanan

Setelah melewati uji fisik, bahan pakan konsentrat disimpan pada gudang penyimpanan sesuai dengan jenis bahan pakan.

PT Indo prima Beef sendiri mengolah 2 jenis konsentrat yang di beri nama F8 dan F9. Konsentrat F8 adalah konsentrat yang memiliki kandungan protein $20 \%$ dan memiliki energi (TDN) $63 \%$. Konsentrat F8 diberikan oleh sapi pada masa grower sedangkan untuk konsentrat F9 memiliki kandungan energi (TDN) 
yang lebih tinggi yaitu $69 \%$ dan kandungan protein yang lebih rendah yaitu $18 \%$. Konsentrat F9 diberikan untuk sapi fase finisher atau sapi yang siap jual. Pergantian konsentrat dari F8 ke konsentrat F9 dilakukan menjelang penjualan yaitu 3-4 minggu sebelum penjualan alasannya karena sapi sudah gemuk dan siap jual sehingga lebih banyak membutuhkan energi untuk menopang bobot badannya.

\section{Pencampuran Konsentrat (Mixing)}

Pencampuran konsentrat di PT Indo Prima Beef dilakukan setelah perencanaan pakan. Hal yang dilakukan adalah menyiapkan bahan-bahan pakan dengan jumlah yang sesuai dengan formulasi ransum dan kebutuhan. Sebelum melakukan pencampuran, terdapat beberapa bahan yang harus dilakukan penggilingan seperti onggok kering. Proses pencampuran bahan pakan konsentrat di PT Indo Prima Beef menggunakan 2 mesin mixing berkapasitas $500 \mathrm{~kg}$ dan waktu yang digunakan untuk mixing yaitu 15-20 menit. Menurut Siregar (2003), pencampuran konsentrat dapat dilakukan secara manual dengan tenaga manusia ataupun dapat dilakukan dengan bantuan mesin.

\section{Pendistribusian Pakan}

Pendistribusian pakan di PT Indo Prima Beef terbagi menjadi 2 yaitu pendistribusian pakan hijauan dan pendistribusian pakan konsentrat. Dalam pendistribusian di PT Indo Prima Beef menggunakan kendaraan mobil pick-up dan motor roda 3 untuk mengangkut hijauan dan konsentrat yang sudah dikarungkan. Bobot perkarung, untuk silase $25 \mathrm{~kg}$, untuk hijauan $30 \mathrm{~kg}$, untuk konsentrat $25 \mathrm{~kg}$.

\section{Pemberian Pakan}

Pakan didistribusikan ke setiap kandang, langkah selanjutnya adalah pemberian pakan. Peran anak kandang sangat dibutuhkan karena anak kandang tidak hanya memberi pakan tetapi mencampur pakan juga. Pemberian pakan di PT Indo Prima Beef dengan tahapan-tahapan pemberian pakan di PT Indo Prima Beef.

1. Anak kandang mengambil pakan yang sudah didistribusikan di pinggir kandang menggunakan roli (angkong)

2. Pakan yang pertama diberikan adalah konsentrat. Tingkat palatabilitas konsentrat di PT Indo Prima Beef sedikit rendah sehingga perlu adanya campuran hijauan. Pencampuran konsentrat dengan hijauan dilakukan dengan cara menaburkan hijauan di depan tempat pakan atau palungan kemudian menaburkan konsentrat di atas hijauan dan aduk dengan menggunakan garuk hingga terlihat merata.

3. Pemberian campuran pakan ke dalam palungan secara merata, dengan bantuan serok,

4. Setelah 2 jam pemberian konsentrat, berikan hijauan kepada ternak.

\section{Persentase Pemberian Pakan}

Pemberian pakan di PT Indo Prima Beef disesuaikan dengan umur sapi datang yang akan digemukan, yaitu:

1. Hari ke-1 dari kedatangan sampai hari ke-3 diberikan pakan hijauan $100 \%$.

2. Hari ke-4 dari kedatangan sapi sampai hari ke-7 mulai diberikan hijauan dan konsentrat dengan perbandingan $50 \%$ hijauan dan 50\% konsentrat.

3. Hari ke-8 dari kedatangan sampai hari ke-20 dengan proporsi $30 \%$ hijauan dan $70 \%$ konsentrat.

4. Hari ke-21 dari kedatangan sapi sampai hari ke-120 dengan proporsi hijauan $20 \%$ dan proporsi konsentrat $80 \%$.

Jumlah pemberian pakan di PT Indo Prima Beef ditentukan oleh formulasi ransum yang telah ditetapkan oleh perusahaan. Perhitungan formulasi ransum disesuaikan oleh beberapa hal yaitu: 
1. Bobot badan maksudnya adalah dalam menghitung formulasi ransum hal pertama yang perlu diketahui adalah bobot badan sapi karena jumlah kebutuhan nutrisi tergantung dari bobot badan sapi.

2. Target ADG (Average Daily Gain) maksudnya adalah berapa jumlah pertambahan bobot badan setiap harinya yang ingin dicapai. Untuk di PT Indo Prima Beef ADG perhari rata-rata 1,6 kg.

3. DOF (Day of Fattening) maksudnya adalah berapa lama sapi tersebut akan digemukan. Di PT Indo Prima Beef DOF disesuaikan berdasarkan jenis kelamin untuk (heifer) 100 hari, untuk (bull) 180 hari, untuk (steer) 120 hari.

Pemberian pakan untuk sapi betina yang sedang hamil (breeding) adalah pakan sisa atau rapen karena sistem pemeliharaan sapi betina yang bunting (breeding) menggunakan sistem (low cost). PT Indo Prima Beef terdapat pakan rapen \pm 24 karung yang dimana setiap kandang terdapat pakan rapen 2 karung perharinya. Feed intake di PT Indo Prima Beef khususnya pada Kandang 8 pen A timur mencapai $90 \%$.

\section{Frekuensi Pemberian}

Frekuensi pemberian pakan di PT Indo Prima Beef dilakukan sebanyak 2 kali yaitu di pagi hari pukul 08.00 WIB dan sore hari pada pukul 14.00 WIB. Ada jarak waktu pemberian antara pemberian konsentrat dan pemberian hijauan. Menurut Siregar (2003), sapi yang akan digemukkan dan memperoleh ransum yang terdiri dari hijauan dan konsentrat harus diatur pemberiannya agar tercapai hasil yang memuaskan. Pemberian hijauan pada sapi yang digemukkan sebaiknya dihindari pemberian yang sekaligus dan dalam jumlah yang banyak. Pemberian yang demikian akan berakibat pada banyaknya hijauan yang terbuang dan tidak dimakan sapi, sehingga tidak efisien.

\section{KESIMPULAN}

Berdasarkan hasil dan pembahasan dapat disimpulkan bahwa tata laksana pengelolaan pakan di PT Indo Prima Beef sudah berjalan cukup baik serta sesuai dengan prosedur perusahaan. Tata laksana pengelolaan pakan di PT Indo Prima Beef meliputi prediksi pakan, pengadaan bahan pakan, pencampuran konsentrat (mixing), pendistribusian dan pemberian pakan.

\section{DAFTAR PUSTAKA}

Abidin, Z. 2009. Penggemukan Sapi Potong. Agromedia Pustaka. Jakarta.

Agus, A. 2008. Panduan Bahan Pakan Ternak Ruminansia. Penerbit Ardana Media. Yogyakarta.

BPS. 2015. Analisis Statistik Pertumbuhan Ekonomi. BPS. Jakarta.

BPTP. 2012. Teknologi Pembuatan silase Komplit. Balai Pengkajian Teknologi Pertanian Kalimantan Tengah. Kalimantan Tengah.

Budiasa, I. K. M. 2015. Ketersediaan hijauan sumber pakan sapi bali berdasarkan penggunaan lahan dan topografi berbeda di Kabupaten Jembrana Provinsi Bali. Tesis. Sekolah Pascasarjana, Institut Pertanian Bogor. Bogor.

Edo. 2012. Hijauan Makanan Ternak. http://ediskoe.blogspot.com/?expref.next-blog. Diakses tanggal 20 Mei 2017

Hermawansetyo. 2014. Mixing dan Mixer Bahan Pakan. http://hermawansetyo.my.id/mixing-dan-mixerbahan-pakan/ 
Kushartono, B., dan N. Iriani. 2009. Prospek Pengembangan Tanaman Jagung Sebagai Sumber Hijauan Pakan Ternak. Balai Penelitian ternak. Bogor.

Santosa, U. 2009. Tata Laksana Pemeliharaan Ternak Sapi. Penebar Swadaya. Jakarta.

Siregar, S.B. 2003. Ransum Ternak Ruminansia. Penebar Swadaya. Jakarta.

Sunarso dan Christiyanto, M. 2008. Manajemen Pakan. Institut Pertanian Bogor. Bogor. 